\title{
UJI EFEK HIPOGLIKEMIK KOMBINASI EKSTRAK ETANOL DAUN SAMBILOTO (Andrographis paniculata Nees) DENGAN AKARBOSE PADA TIKUS PUTIH (Rattus norvegicus) TERINDUKSI ALOKSAN
}

\author{
Sukmawati, Muhammad Akbar Harsita, Rachmat Kosman \\ Fakultas Farmasi Universitas Muslim Indonesia \\ Email : sukmawati.sukmawati@umi.ac.id
}

\begin{abstract}
Acarbose and sambiloto have the same mechanism of action in lowering blood glucose levels by inhibiting alfaglukosidase enzymes in the gut. This study aims to determine the hypoglycemic effect and combination effect from ethanol extract of sambiloto leaves (Andrographis paniculata Nees) with acarbose in rat (Rattus norvegicus) induced alloxan. Twelve Wistar rats were divided into 4 groups; negative control, positive control, and two treatment groups (EEDS $59 \mathrm{mg} / \mathrm{kgBW}$ with Acarbose 2,05 mg/kgBB as combination I and EEDS $234 \mathrm{mg} / \mathrm{kgBW}$ with Acarbose $2,05 \mathrm{mg} / \mathrm{kgBB}$ as combination II). Diabetes Mellitus was induced by Aloksan Monohidrate dose $135 \mathrm{mg} / \mathrm{kg}$ BB for three days. Level of blood glucose was measured with glukometer at 2, 4, 6 and 8 day. Treatment with combinations of EEDS doses 59 and $234 \mathrm{mg} / \mathrm{kgBW}$ and Acarbose 2,05 mg/kgBB for 7 days significantly decreased blood glucose level $(p<0,05)$ by $48,97 \%$, and $58,81 \%$ respectively.
\end{abstract}

Keywords : Hipoglicemic, Andrographis paniculata Nees., Blood glucose level, Acarbose, Combination.

\section{PENDAHULUAN}

Diabetes mellitus (DM) adalah penyakit yang disebabkan penurunan sekresi insulin oleh kelenjar pankreas. Sehingga mengakibatkan kadar glukosa di dalam tubuh akan meningkat. ${ }^{1}$

Penderita diabetes di Indonesia pada tahun 2010 berjumlah 21,3 juta orang. ${ }^{2}$ Sementara menurut data Diabetes Atlas 2000 (IDF) pasien DM di Indonesia adalah 5,6 juta dan pada tahun 2020 diperkirakan akan meningkat menjadi 8,2 juta. Hal ini membuktikan bahwa penyakit diabetes mellitus merupakan masalah kesehatan yang sangat serius. ${ }^{3}$

Akarbose merupakan obat oral untuk mengobati diabetes type-2 (noninsulin dependance). Akarbose merupakan penghambat enzim $\alpha$ glukosidase yang bekerja menghambat penyerapan karbohidrat dengan menghambat enzim disakarida di usus. Efek samping yang paling sering dikeluhkan adalah produksi gas 
Uji Efek Hipoglikemik Kombinasi Ekstrak Etanol Daun Sambiloto (Andrographis paniculata Nees) Dengan Akarbose Pada Tikus Putih (Rattus norvegicus) Terinduksi Aloksan

dalam perut dan diare, khususnya setelah konsumsi makanan tinggi karbohidrat. ${ }^{4}$

Selain penggunaan obat kimia, obat tradisional juga menjadi rekomendasi penatalaksanaan terapi DM. Sambiloto (Andrographis paniculata Nees) adalah tanaman yang mengandung andrographolide 46\%. Dimana kandungan tersebut dapat mengurangi kadar glukosa darah. $^{5}$

Ekstrak sambiloto juga dapat merangsang pelepasan insulin dan menghambat absorbsi glukosa melalui penghambatan enzim alfaglukosidase dan alfa-amilase. ${ }^{6}$ Menurut penelitian yang dilakukan oleh Kastilani Sarah (2009) bahwa pemberian ekstrak etanol daun sambiloto dosis 29,5 $\mathrm{mg} / \mathrm{kgBB}$ dan dosis $117 \mathrm{mg} / \mathrm{kgBB}$ efektif menurunkan kadar glukosa darah mencit. ${ }^{7}$

Ditinjau dari segi mekanisme kerja sambiloto dan akarbose yang mempunyai kesamaan dalam menghambat enzim alfaglukosidase untuk menurunkan kadar glukosa darah, maka perlu dilakukan penelitian untuk menguji apakah kombinasi ekstrak etanol daun sambiloto dengan obat akarbose dapat menghasilkan efek yang sinergis untuk memaksimalkan penurunan kadar glukosa darah. Karena berdasarkan hasil penelitian sebelumya yang dilakukan oleh Syamsul, dkk. (2011) tentang kombinasi herba sambiloto dengan obat metformin yang mempunyai mekanisme kerja yang berbeda, ternyata memperoleh hasil bahwa kombinasi ekstrak herba sambiloto dengan metformin tidak meningkatkan potensi antidiabetes. ${ }^{8}$

\section{METODE PENELITIAN}

\section{Jenis Penelitian}

Jenis penelitian yang digunakan yaitu true eksperimental meliputi tiga komponen yaitu kontrol, randomisasi, dan replikasi. Rancangan penelitian yaitu pre-post test control group desain. $^{9}$

\section{Alat dan Bahan}

Alat yang digunakan adalah glukometer (Easy touch ${ }^{\circledR}$ ), restrainer, rotavapor, dan spoit oral. Sedangkan bahan yang digunakan adalah aloksan, aquadest, ekstrak etanol daun Sambiloto (Andrographis paniculata Nees) (EEDS), etanol $96 \%$, $\mathrm{NaCl}$ 0,9\%, Na.CMC 1\%, dan tablet akarbose. Hewan uji yang digunakan adalah tikus putih (Rattus norvegicus) umur 3-4 bulan dengan berat badan 150-200 gram sebanyak 12 ekor. 
Uji Efek Hipoglikemik Kombinasi Ekstrak Etanol Daun Sambiloto (Andrographis paniculata Nees) Dengan Akarbose Pada Tikus Putih (Rattus norvegicus) Terinduksi Aloksan

Prosedur Kerja

\section{Penyiapan dan pengolahan sampel}

Sampel daun sambiloto (Andrographis paniculata Nees) yang diperoleh dari Makassar. Pengambilan sampel dilakukan pada pagi hari sekitar 10.00. Bagian yang diambil adalah daun. Sampel dibersihkan dari kotoran yang melekat dengan menggunakan air yang mengalir lalu dikeringkan dengan cara dianginanginkan tanpa terkena sinar matahari langsung, kemudian sampel dipotongpotong kecil.

Pembuatan ekstrak etanol daun sambiloto (Andrographis paniculata Nees)

Sebanyak 200 gram simplisia dimaserasi dengan etanol 70\% 1000 $\mathrm{ml}$ selama $5 \times 24$ jam, kemudian disaring dan ampasnya direndam kembali dengan cairan penyari yang baru, hasil penyarian yang diperoleh dipekatkan dengan menggunakan rotavapor sampai diperoleh ekstrak etanol pekat, kemudian diuapkan lagi hingga didapatkan ekstrak kental dan ditimbang.

\section{Pembuatan aloksan $135 \mathrm{mg} / \mathrm{kg}$ BB}

Ditimbang aloksan $540 \mathrm{mg}$ kemudian dilarutkan dengan $\mathrm{NaCl}$ fisiologis $0,9 \%$ sedikit demi sedikit hingga larut dan dicukupkan volumenya hingga $20 \mathrm{ml}$, kemudian dimasukkan kedalam wadah tertutup baik.

\section{Pembuatan suspensi Na-CMC 1\%}

Sebanyak 1 gram Na.CMC dimasukkan sedikit demi sedikit kedalam $50 \mathrm{ml}$ air air suling panas $\left(70^{\circ} \mathrm{C}\right)$ sambil diaduk dengan menggunakan pengaduk elektrik hingga terbentuk larutan koloidal yang homogen, kemudian dicukupkan volumenya hingga $100 \mathrm{ml}$ dengan air suling. ${ }^{10}$

\section{Pembuatan suspensi akarbose}

Dosis akarbose pada manusia dewasa adalah $100 \mathrm{mg}$, jika dikonversikan pada tikus dengan berat $200 \mathrm{~g}$ adalah 2,05 mg/gBB, maka dosis acarboce untuk tikus adalah 2,05 $\mathrm{mg} / \mathrm{gBB}$. Sehingga ditimbang 25,47 mg acarbose kemudian dicukupkan volumenya dengan $\mathrm{NaCMC} 1 \%$ hingga $10 \mathrm{~mL}$ untuk sehari perlakuan.

Pembuatan sediaan ekstrak etanol daun sambiloto (Andrographis paniculata Nees.) (EEDS)

Simplisia dari ekstrak etanol daun sambiloto (EEDS) dibuat dalam dosis $59 \mathrm{mg} / \mathrm{kgBB}$ dan $234 \mathrm{mg} / \mathrm{kgBB}$. Cara pembuatan sediaan EEDS 59 $\mathrm{mg} / \mathrm{kgBB}$ dan EEDS $234 \mathrm{mg} / \mathrm{kgBB}$ yaitu ditimbang masing-masing ekstrak sebanyak $59 \mathrm{mg}$ dan $234 \mathrm{mg}$ kemudian masing - masing 
Uji Efek Hipoglikemik Kombinasi Ekstrak Etanol Daun Sambiloto (Andrographis paniculata Nees) Dengan Akarbose Pada Tikus Putih (Rattus norvegicus) Terinduksi Aloksan

disuspensikan dengan Na-CMC 1\% sebanyak $10 \mathrm{~mL}$.

\section{Perlakuan terhadap hewan coba}

Tahap pertama tikus diadaptasi selama \pm 7 hari, selanjutnya diukur kadar glukosa puasanya sebagai data awal. Setelah itu, masing-masing tikus diinduksi aloksan $135 \mathrm{mg} / \mathrm{kgBB}$ secara intraperitoneal. Pengukuran kadar glukosa dilakukan pada hari ke-3 setelah penginduksian. Selanjutnya dilakukan randomisasi yakni membagi tikus menjadi empat kelompok. Tahap selanjutnya adalah pengujian bahan uji dengan perlakuan sebagai berikut : kelompok I diberikan NaCMC 1\% sebagai kontrol negatif, kelompok II diberikan akarbose 2,05 $\mathrm{mg} / \mathrm{kgBB}$ sebagai kontrol positif, kelompok III diberi ekstrak etanol daun Sambiloto (Andrographis paniculata Nees.) / EEDS dosis $59 \mathrm{mg} / \mathrm{kgBB}$ dengan akarbose 2,05 mg/kgBB sebagai kombinasi I, kelompok IV diberi ekstrak etanol daun Sambiloto
(Andrographis paniculata Nees.) / EEDS dosis $234 \mathrm{mg} / \mathrm{kgBB}$ dengan akarbose 2,05 mg/kgBB sebagai kombinasi II. Semua perlakuan diberikan secara oral dan dilakukan selama 7 hari. Selama perlakuan tersebut dilakukan pengukuran kadar glukosa darah pada hari ke 2, 4, 6 dan 8 dengan menggunakan alat glukometer.

\section{Pengukuran kadar glukosa darah} pada hewan uji

Pengukuran kadar glukosa darah dilakukan dengan cara diambil darah melalui ujung ekor kemudian diteteskan pada strip glukometer dan secara otomatis akan terbaca pada layar monitor glukometer.

\section{Analisis data}

Data yang diperoleh dari hasil pengukuran kadar glukosa darah dianalisa secara statistik menggunakan program SPSS (Statistical Product and Service Solutions) dan metode one way anova. 
Uji Efek Hipoglikemik Kombinasi Ekstrak Etanol Daun Sambiloto (Andrographis paniculata Nees) Dengan Akarbose Pada Tikus Putih (Rattus norvegicus) Terinduksi Aloksan

HASIL PENELITIAN

Hasil pengujian kombinasi akarbose terhadap tikus putih terinduksi aloksan dapat dilihat pada tabel 1 berikut :

Tabel 1. Hasil rata-rata pengukuran kadar glukosa darah tikus selama 7 hari perlakuan

\begin{tabular}{cccccc}
\hline \multirow{2}{*}{ Kelompok } & \multicolumn{5}{c}{ Rata-rata Kadar Glukosa Darah (mg/dL) \pm SD } \\
\cline { 2 - 6 } & Hari ke 0 & Hari ke 2 & Hari ke 4 & Hari ke 6 & Hari ke 8 \\
\hline Kontrol Negatif & $240 \pm 13,61$ & $237 \pm 14,36$ & $235 \pm 13,8$ & $232 \pm 15,04$ & $231 \pm 14$ \\
Kontrol Positif & $268 \pm 20,20$ & $247 \pm 19.5$ & $211 \pm 16,7$ & $165 \pm 24,19$ & $133 \pm 14,98$ \\
Kombinasi I & $261 \pm 8,02$ & $231 \pm 13,2$ & $205 \pm 14,5$ & $171 \pm 15,01$ & $133 \pm 20,11$ \\
Kombinasi II & $276 \pm 29,67$ & $233 \pm 31,77$ & $200 \pm 34,1$ & $150 \pm 30,98$ & $115 \pm 36,17$ \\
\hline
\end{tabular}

Data pengamatan tersebut di atas dilakukan perhitungan persentase penurunan kadar glukosa darah tikus.

Tabel 2. Hasil rata-rata persentase penurunan kadar glukosa darah tikus setelah 7 hari pemberian sediaan uji pada semua kelompok

\begin{tabular}{cc}
\hline Kelompok & Persentase penurunan \\
\hline Kontrol Negatif & $3,89 \pm 0,59^{\mathrm{a}}$ \\
Kontrol Positif & $50,34 \pm 3,46^{\mathrm{b}}$ \\
Kombinasi I & $48,97 \pm 8,27$ \\
Kombinasi II & $58,81 \pm 8,37$ \\
\hline
\end{tabular}

Data disajikan dalam bentuk Mean \pm SD

${ }^{\mathrm{a}} \mathrm{P}<0.05$ dengan semua kelompok perlakuan $(L S D$ test)

${ }^{\mathrm{b}} \mathrm{P}>0.05$ dengan kedua kelompok dosis kombinasi (LSD test)

\section{PEMBAHASAN}

Penelitian ini bertujuan untuk menentukan efek hipoglikemik dan kombinasi yang efektif dari ekstrak etanol daun sambiloto (Andrographis paniculata Nees) dengan akarbose pada tikus putih (Rattus norvegicus) yang terinduksi aloksan. Daun sambiloto digunakan sebagai sampel karena sambiloto mengandung senyawa andrographolide, dimana senyawa ini dapat mengurangi kadar glukosa darah. Sementara akarbose digunakan sebagai sampel kombinasi pemberiannya dengan daun sambiloto. Hal tersebut berdasarkan hasil kajian mekanisme kerja akarbose dan daun sambiloto yaitu memiliki mekanisme kerja yang sama dalam menghambat enzim alfaglukosidase sehingga efek sinergis dalam menurunkan kadar glukosa dapat diperoleh.

Bahan kimia diabetonik yang digunakan yaitu aloksan monohidrat. 
Uji Efek Hipoglikemik Kombinasi Ekstrak Etanol Daun Sambiloto (Andrographis paniculata Nees) Dengan Akarbose Pada Tikus Putih (Rattus norvegicus) Terinduksi Aloksan

Aloksan monohidrat mempunyai mekanisme kerja yaitu merusak sel $\beta$ pankreas. Menurut Szkudelski (2006) mekanisme toksisitas aloksan diawali dengan masuknya aloksan ke dalam sel-sel $\beta$ pankreas. Kerusakan pada sel $\beta$ terjadi melalui beberapa proses secara bersamaan, yaitu melalui oksidasi gugus sulfidril dan pembentukan radikal bebas. Aloksan menyerang senyawa-senyawa seluler yang mengandung gugus sulfidril, asam-asam amino sistein dan protein yang berikatan dengan gugus $\mathrm{SH}$ (termasuk enzim yang mengandung gugus $\mathrm{SH}$ ). Radikal bebas tersebut dapat menyerang komponen penyusun sel sehingga menyebabkan kerusakan sel. $^{11}$

Penelitian ini menggunakan akarbose sebagai pembanding. Akarbose merupakan penghambat enzim a-glukosidase yang bekerja menghambat penyerapan karbohidrat dengan menghambat enzim disakarida di usus. Obat ini terutama menurunkan glukosa darah setelah makan. ${ }^{4}$

Hasil pengamatan terhadap penurunan kadar glukosa darah tikus selama perlakuan dapat dilihat pada tabel 1 dimana semua kelompok perlakuan menggambarkan penurunan kadar glukosa darah hingga akhir terapi menunjukkan bahwa kelompok
Na-CMC $1 \%$ setelah diinduksi mengalami peningkatan kadar glukosa darah. Namun, setelah terapi mengalami penurunan kadar glukosa darah walaupun tidak begitu berarti sebesar 3,89\%. Kelompok akarbose 2,05 mg/kgBB mengalami peningkatan kadar glukosa darah setelah diinduksi dan mengalami penurunan kadar glukosa darah setelah terapi sebesar 50,34\%. Berdasarkan penurunan yang terjadi akarbose dapat menurunkan kadar glukosa darah hingga batas normal. Sedangkan kelompok uji (III) EEDS $59 \mathrm{mg} / \mathrm{kgBB}$ dengan akarbose 2,05 $\mathrm{mg} / \mathrm{kgBB}$ dan kelompok uji (IV)EEDS $234 \mathrm{mg} / \mathrm{kgBB}$ dengan akarbose 2,05 mg/kgBB mengalami peningkatan kadar glukosa darah setelah diinduksi dan mengalami penurunan kadar glukosa darah setelah diterapi hingga hari ke-8. Penurunan kadar glukosa yang terjadi setelah terapi dapat ditekan hingga batas normal untuk kelompok ketiga EEDS $59 \mathrm{mg} / \mathrm{kgBB}$ dengan akarbose $2,05 \mathrm{mg} / \mathrm{kgBB}$ sebesar 48,97\% dan $58,81 \%$ untuk kelompok keempat EEDS $234 \mathrm{mg} / \mathrm{kgBB}$ dengan akarbose 2,05 mg/kgBB. Berdasarkan penurunan yang terjadi dapat dilihat bahwa pada kelompok uji, EEDS 234 $\mathrm{mg} / \mathrm{kgBB}$ dengan akarbose 2,05 
Uji Efek Hipoglikemik Kombinasi Ekstrak Etanol Daun Sambiloto (Andrographis paniculata Nees) Dengan Akarbose Pada Tikus Putih (Rattus norvegicus) Terinduksi Aloksan

$\mathrm{mg} / \mathrm{kgBB} \quad$ yang lebih baik obat akarbose,

senyawa

penurunannya (tabel 2 dan gambar 1).

Kelompok uji kombinasi EEDS

$59 \mathrm{mg} / \mathrm{kgBB}$ dengan akarbose 2,05 $\mathrm{mg} / \mathrm{kgBB}$ dan EEDS $234 \mathrm{mg} / \mathrm{kgBB}$ dengan akarbose 2,05 $\mathrm{mg} / \mathrm{kgBB}$ mengalami penurunan yang agak jauh berbeda, jika dilihat dari profil penurunannya menunjukkan bahwa kombinasi EEDS $234 \mathrm{mg} / \mathrm{kgBB}$ dengan akarbose 2,05 $\mathrm{mg} / \mathrm{kgBB}$ memiliki efek penurunan glukosa darah lebih baik dibandingkan terhadap kelompok pembanding akarbose 2,05 mg/kgBB dan kelompok uji kombinasi EEDS $59 \mathrm{mg} / \mathrm{kgBB}$ dengan akarbose 2,05 mg/kgBB.

Data hasil pengukuran kadar glukosa darah dianalisis secara statistik dengan metode analisa one way anova dilanjutkan dengan uji post hoc yaitu LSD (dapat dilihat pada tabel. 2). Hasil uji tersebut menunjukkan bahwa kelompok kontrol positif yang diberikan akarbose dosis 2,05 $\mathrm{mg} / \mathrm{kgBB}$ memiliki efek hipoglikemik yang sama dengan ekstrak etanol daun sambiloto dosis 59 $\mathrm{mg} / \mathrm{kgBB}$ dengan akarbose 2,05 $\mathrm{mg} / \mathrm{kgBB}$ dan ekstrak etanol daun sambiloto dosis $234 \mathrm{mg} / \mathrm{kgBB}$ dengan akarbose 2,05 mg/kgBB (p>0,05). Berdasarkan interaksi yang terjadi antara ekstrak daun sambiloto dengan andrographolide yang terdapat pada ekstrak daun sambiloto dapat menimbulkan efek yang sinergis dengan obat akarbose sehingga dapat menurunkan kadar glukosa darah secara signifikan. Berdasarkan nilai rata-rata persentase penurunan kadar glukosa darah pasca-terapi, ekstrak yang memiliki efek hipoglikemik paling efektif yaitu ekstrak etanol daun sambiloto dosis $234 \mathrm{mg} / \mathrm{kgBB}$ dengan akarbose 2,05 mg/kgBB dengan persentase penurunan sebesar $58,81 \%$.

\section{KESIMPULAN}

Berdasarkan hasil penelitian dan pembahasan disimpulkan bahwa kombinasi ekstrak etanol daun sambiloto dengan akarbose memiliki efek hipoglikemik pada tikus putih yang terinduksi aloksan. Kombinasi ekstrak etanol daun sambiloto 234 $\mathrm{mg} / \mathrm{kgBB}$ dengan akarbose 2,05 $\mathrm{mg} / \mathrm{kgBB}$ yang efektif dalam menurunkan kadar glukosa darah tikus terinduksi aloksan.

\section{DAFTAR PUSTAKA}

1. Utami P. Tanaman Obat Untuk Mengatasi Diabetes Mellitus. Jakarta: Agromedia, 2003.

2. Gustina N. Aktivitas Ekstrak, Fraksi Pelarut dan Senyawa Flavonoid Daun Sukun (Artocarpus atlitis) Terhadap Enzim a-Glukosidase 
Uji Efek Hipoglikemik Kombinasi Ekstrak Etanol Daun Sambiloto (Andrographis paniculata Nees) Dengan Akarbose Pada Tikus Putih (Rattus norvegicus) Terinduksi Aloksan

Sebagai Antidiabetes (Skripsi).

Bogor : Departemen Biokimia Fakultas Matematika dan IImu pengetahuan Alam Institut Pertanian Bogor, 2012.

3. Suhardjono, Arsita D. Pengaruh Pemberian Infus Biji Alpukat (Persea Americana Mill.) Terhadap Kadar Glukosa Darah Tikus Wistar Yang Diberi Beban Glukosa (Skripsi). Semarang: Fakultas Kedokteran Universitas Diponegoro, 2006.

4. Katzung BG. Farmakologi Dasar dan Klinik edisi 8 buku 2. Jakarta : Penerbit Salemba Medika, 2002.

5. Widyawati T. Aspek farmakologi sambiloto (andrographis paniculata nees). Sumatra Utara : Departemen Farmakologi dan Terapeutik Fakultas Kedokteran Sumatra Utara, 2007.

6. Subramanian $R$, Asmawi MZ, Sadikun A. In Vitro AlphaGlucosidase and Alpha-Amylase Enzyme Inhibitory Effects of Andrographis paniculata Extract and Andrographolide. Acta Biochemistry Policy 2008;55(2): 391- 398.
7. Kastilani etanol

S. Pengaruh ekstrak (Andrographis folium) terhadap kadar glukosa darah mencit jantan galur swiss webster yang diinduksi aloksan dan perbandingannya dengan Jamu D. Yogyakarta : Universitas Gadjah Mada, 2009.

8. Syamsul ES, Nugroho AE, Pramono S.. Aktivitas Antidiabetes Kombinasi Ekstrak Terpurifikasi Herba Sambiloto (Andrographis paniculata (Burn.F.) NESS.) dan Metformin pada Tikus DM Tipe 2 Resisten Insulin. Majalah Obat Tradisional 2011;16(3): 124 - 131.

9. Zainuddin M. Metodologi Penelitian: Kefarmasiaan dan Kesehatan. Surabaya: Airlangga University Press, 2011.

10. Parrot EL. Pharmaceutical Technology Fundamental Pharmaceutics. Minnepolis: BurgessPublishing Company, 1979.

11. Szkudelski T. The Mechanism Of Alloxan And Streptozotocin Action In $\beta$ Cells of The Rat Pancreas. Physiology Research 2001;50: 536-54. 